\title{
Filozoficzne zarzuty stawiane hipotezie inteligentnego projektu: odpowiedź na krytykę *
}

\section{Czy hipoteza inteligentnego projektu jest falsyfikowalna?}

Część recenzentów mojej książki Darwin's Black Box ${ }^{1}$ postawiła filozoficzne zarzuty hipotezie inteligentnego projektu. W kilku następnych podrozdziałach tego artykułu omówię niektóre $\mathrm{z}$ nich, zaczynając od kwestii falsyfikowalności. Aby zdecydować, czy hipoteza ta $\mathrm{w}$ ogóle jest falsyfikowalna lub dzięki jakiemu świadectwu empirycznemu można ją sfalsyfikować, trzeba mieć najpierw pewność, co rozumie się przez ,inteligentny projekt”. Przez owo wyrażenie można rozumieć to, że same prawa przyrody są zaprojektowane w celu wytwarzania życia i złożonych systemów, które leżą u jego podstaw. Mniej więcej takie stanowisko zajęli w swoich książkach fizyk Paul Davies i genetyk Michael Denton, odpowiednio wThe Fifth Miracle:

*M.J. Behe, „Philosophical Objections to Intelligent Design: Response to Critics”, Discovery Institute, 31 lipca 2000, http://www.discovery.org/scripts/viewDB/index.php?com mand=view\&id=445. Z języka angielskiego za zgodą Autora przełożył Dariusz SAGAN. Recenzent: Grzegorz Nowak, Zakład Biochemii UMCS, Lublin.

${ }^{1}$ M.J. Behe, Darwin's Black Box: The Biochemical Challenge to Evolution, The Free Press, New York 1996. 
The Search for the Origin and Meaning of Life ${ }^{2}$ i Nature's Destiny: How the Laws of Biology Reveal Purpose in the Universe. ${ }^{3}$ Stanowisko to wydaje się możliwe do zaakceptowania przez National Academy of Sciences:

Wiele religijnych osób, łącznie z wieloma naukowcami, utrzymuje pogląd, że Bóg stworzył Wszechświat oraz rozmaite procesy kierujące fizyczną i biologiczną ewolucją, jak również, że dzięki tym procesom utworzyły się następnie galaktyki, nasz Układ Słoneczny i życie na Ziemi. To przekonanie, nazywane czasem „teistycznym ewolucjonizmem”, nie jest niezgodne z naukowymi wyjaśnieniami ewolucjonizmu. W rzeczywistości odzwierciedla ono niezwykły i inspirujący charakter fizycznego wszechświata, ukazanego przez [naukę]. ${ }^{4}$

W takim ujęciu, nawet jeśli zaobserwujemy w przyrodzie lub laboratorium, że przy pomocy nacisku selekcyjnego wytworzono nowe złożone układy, hipoteza projektu i tak nie zostanie sfalsyfikowana, ponieważ rozważa się ją jako wbudowaną w prawa natury. Pozwólcie, że nie komentując zalet tego stanowiska powiem, iż nie takie znaczenie przypisuję owemu wyrażeniu. Używając wyrażenia ,inteligentny projekt", daję do zrozumienia, że projekt przekracza prawa przyrody. To znaczy, przyjmując prawa przyrody jako dane, należy zapytać, czy istnieją inne powody do wyciągnięcia wniosku, że życie i składające się na nie systemy zaplanowano celowo? W mojej książce i w tym eseju, ilekroć odwołuję się do inteligentnego projektu (ID), mam na myśli ten mocniejszy sens - projekt-poza-prawami. Właściwie wszyscy akademiccy krytycy mojej książki rozumieli owo wyrażenie w owym mocnym sensie.

\footnotetext{
${ }^{2}$ P.C.W. DAVIES, The Fifth Miracle: The Search for the Origin and Meaning of Life, Simon \& Schuster, New York 1999.

${ }^{3}$ M.J. Denton, Nature's Destiny: How the Laws of Biology Reveal Purpose in the Universe, Free Press, New York 1998.

${ }^{4}$ National Academy of Sciences, Science and Creationism: A View from the National Academy of Sciences, National Academy Press, Washington, DC. 1999, s. 7.
} 
W mocnym sensie hipoteza ID nie jest akceptowana przez $\mathrm{Na}$ tional Academy ze szczególnego powodu: ,[I]nteligentny projekt... [jest] nienaukowy, ponieważ nie [jest] testowalny metodami naukowymi". ${ }^{5}$ W swojej recenzji Darwin's Black Box dla Nature Jerry Coyne profesor biologii ewolucyjnej w University of Chicago - wyjaśnia, dlaczego on również uważa, że hipoteza inteligentnego projektu jest niefalsyfikowalna.

Jeśli akceptuje się ideę Behe'ego, że ewolucja i stworzenie mogą ze sobą współdziałać, oraz że cele Projektanta są niezgłębione, to otrzymuje się hermetyczną teorię, której nie można obalić. Mogę wyobrazić sobie świadectwo empiryczne, które sfalsyfikowałoby ewolucjonizm (dobrym falsyfikatorem byłoby znalezienie skamieniałości hominida w warstwie prekambryjskiej), ale żadnego świadectwa, które mogłoby sfalsyfikować złożoną teorię Behe’ego. Nawet gdyby ogromnym wysiłkiem udało się zrozumieć ewolucję jakiegoś złożonego procesu biochemicznego, Behe mógłby z łatwością twierdzić, że świadectwo empiryczne na rzecz projektu znajduje się w innym niewyjaśnionym procesie. Nigdy nie wyjaśnimy wszystkiego i dlatego zawsze znajdzie się świadectwo na rzecz projektu. Ten wsteczny kreacjonizm ad hoc może wydawać się pomysłowy, ale $\mathrm{z}$ pewnością nie jest naukowy. ${ }^{6}$

Wniosek Coyne'a, że hipoteza projektu jest niefalsyfikowalna, wydaje się jednak nie zgadzać $\mathrm{z}$ argumentami innych recenzentów mojej książki. Jest dla mnie jasne, że Russell Doolittle ${ }^{7}$, Kenneth Miller ${ }^{8}$ i inni wysunęli argumenty naukowe w celu sfalsyfikowania hipotezy ID. (Zobacz moje artykuły o krzepnięciu krwi i teście Kennetha Millera na zdolność doboru naturalnego do tworzenia nieredukowalnej złożoności, zamieszczone na stronie internetowej www.discovery.org). Gdyby wyniki doświadczeń z myszami, którym usunięto pewne ukła-

${ }^{5}$ Tamże, s. 25.

${ }^{6}$ J.A. Coyne, „God in the details”, Nature 1996, vol. 383, s. 227-228.

${ }^{7}$ R.F. Doolitle, „A delicate balance”, Boston Review, luty/marzec 1997, s. 28-29.

${ }^{8}$ K.R. Miller, Finding Darwin's God: A Scientist's Search for Common Ground Between God and Evolution, Cliff Street Books, New York 1999. 
dy biochemiczne, ${ }^{9}$ były takie, jak Doolittle najpierw myślał lub gdyby praca Barry'ego Halla ${ }^{10}$ rzeczywiście pokazała to, co sugerował Miller, to poprawnie mniemaliby, że moim twierdzeniom o nieredukowalnej złożoności zadano spory cios. A skoro moje twierdzenie o inteligentnym projekcie wymaga, żeby żaden nieinteligentny proces nie wystarczał do wytworzenia systemów nieredukowalnie złożonych, więc wiarygodność hipotezy ID ogromnie by ucierpiała. Inni naukowcy, łącznie z tymi, którzy zasiadają w National Academy of Sciences Steering Committee on Science and Creationism, komentując moją książkę również wskazali na fizyczne świadectwo (takie jak podobne struktury hemoglobiny i mioglobiny), na podstawie którego zamierzali pokazać, że nieredukowalnie złożone układy biochemiczne można wytworzyć poprzez dobór naturalny: ,Jednakże struktury i procesy, o których sądzi się, że są «nieredukowalnie» złożone, po bliższym przyjrzeniu się im przestają sprawiać takie wrażenie". ${ }^{11}$

Nie można jednak mieć dwóch rzeczy naraz. Nie można mówić, że hipoteza ID jest niefalsyfikowalna (lub nietestowalna) i że istnieje świadectwo empiryczne, które jej zaprzecza. Albo jest niefalsyfikowalna i nieczuła na zarzuty doświadczalne, albo można ją krytykować na podstawie obserwacji i dlatego jest testowalna. Fakt, że krytyczni recenzenci wysuwają naukowe argumenty przeciw hipotezie ID (mniejsza o to, czy odnosząc sukces, czy nie) pokazuje, że w rzeczywistości jest ona falsyfikowalna.

Mój argument na rzecz inteligentnego projektu jest otwarty na bezpośrednie obalenie poprzez wyniki doświadczenia. Oto eksperyment myślowy, który rozjaśni trochę to spostrzeżenie. W Darwin's Black Box twierdziłem, że wić bakteryjna jest nieredukowalnie złożo-

\footnotetext{
${ }^{9}$ T.H. Bugge, K.W. Kombrinck, M.J. Flick, C.C. Daugherty, M.J. Danton, and J.L. Degen, „Loss of fibrinogen rescues mice the pleiotropic effects of plasminogen deficiency”, Cell 1996, vol. 87, s. 709-719.

${ }^{10}$ B.G. HaLl, „Experimental evolution of Ebg enzyme provides clues about the evolution of catalysis and to evolutionary potential", FEMS Microbiology Letters 1999, vol. 174, s. 1-8.

${ }^{11}$ National Academy of Sciences, Science and Creationism..., s. 22.
} 
na i dlatego należy rozważyć hipotezę inteligentnego projektu. W twierdzeniu owym chodzi o to, że dobór naturalny działający na przypadkową zmienność lub jakikolwiek inny nieinteligentny proces nie mógł wytworzyć wici. Aby sfalsyfikować takie twierdzenie, naukowiec mógłby pójść do laboratorium, poddać naciskowi selekcyjnemu (np. na zdolność do poruszania się) gatunek bakterii, który nie ma wici, poczekać, aż pojawi się dziesięciotysięczne pokolenie bakterii i zobaczyć, czy wytworzy się wić lub jakikolwiek inny, równie złożony układ. Gdyby tak się stało, definitywnie obalonoby moje twierdzenie. ${ }^{12}$

A co ze zmartwieniem wyrażonym przez profesora Coyne'a, że gdyby pokazano, iż jakiś jeden system powstał na skutek działania doboru naturalnego, to i tak zwolennicy hipotezy ID twierdziliby, że jakiś inny system został zaprojektowany? Uważam, że zarzut ten ma małą siłę. Gdyby pokazano, że dobór naturalny może wytworzyć układ o pewnym stopniu złożoności, to można byłoby założyć, że jest on w stanie wytworzyć jakikolwiek inny układ o równie dużym lub mniejszym stopniu złożoności. Gdyby Coyne zademonstrowal, że dobór naturalny może wytworzyć wić (która wymaga blisko czterdziestu produktów genowych), byłbym raczej głupcem, gdybym potem zapewniał, że powstanie systemu krzepnięcia krwi (który składa się z około dwudziestu białek) wymagało udziału inteligentnego projektu.

\footnotetext{
${ }^{12}$ Kenneth Miller sugeruje czytelnikom swojej książki Finding Darwin's God, że taki proces może być bardzo łatwy do przeprowadzenia. Pisze on: „skoro mikroewolucja może przeprojektować jeden gen w ciągu mniej niż dwustu pokoleń (co w tym przypadku zajęło tylko trzynaście dni), to jakie zasady biochemii czy biologii molekularnej nie pozwolą na przeprojektowanie setek genów w ciągu kilku tygodni lub miesięcy i stworzenie w ten sposób zupełnie innego, nowego gatunku? Oczywiście, nie ma takich zasad [...]" (Miller, Finding Darwin's God..., s. 108). Dlaczego zatem nie weźmie on jakiegoś stosownego gatunku bakterii, nie wyeliminuje z niego genów na wić, nie podda naciskowi selekcyjnemu (np. na zdolność do poruszania się) i nie wytworzy eksperymentalnie w laboratorium wici lub jakiegokolwiek innego, równie złożonego systemu? (Wić ma w końcu tylko 30-40 genów, a nie setki, jak twierdzi Miller, więc dobór naturalny mógłby łatwo i szybko ją przeprojektować). Gdyby Miller to zrobił, moje twierdzenia zostałyby całkowicie sfalsyfikowane. Nie uczyni on tego jednak, ponieważ rażąco wyolbrzymia perspektywę osiągnięcia sukcesu na tym polu.
} 
Spójrzmy teraz $\mathrm{z}$ drugiej strony i zapytajmy, jak można sfalsyfikować twierdzenie, że - dajmy na to - wić bakteryjna została wytworzona przy pomocy procesów darwinowskich? (Uwagi profesora Coyne'a o prekambryjskiej skamieniałości hominida nie są tutaj ważne, gdyż ja rozważam mechanizm doboru naturalnego, a nie wspólne pochodzenie. Podobnie jak on, nie spodziewam się znaleźć skamieniałości hominida poza sekwencją, w której są one znajdowane). Gdyby jakiś naukowiec poszedł do laboratorium, poddawał naciskowi selekcyjnemu przez wiele pokoleń pozbawiony wici gatunek bakterii i nie stałoby się właściwie nic, to czy darwiniści przekonaliby się o niezdolności doboru naturalnego do wytworzenia wici? Wątpię. Zawsze można twierdzić, że zastosowano niewłaściwy nacisk selekcyjny, albo że zaczęto od niewłaściwego gatunku bakterii, i tak dalej. Podejrzewam, że nawet gdyby wiele razy powtórzono eksperyment $\mathrm{w}$ różnych warunkach, a wynik zawsze byłby negatywny, to i tak wielu darwinistów nie wyciągnęłoby stąd wniosku, że twierdzenie ewolucjonizmu darwinowskiego zostało sfalsyfikowane. Sam Coyne pisze o złożonych układach biochemicznych, że „być może nigdy nie będziemy w stanie wyobrazić sobie pierwszych protoprocesów. Nie jest jednak wiążące założenie, iż takie procesy nie istniały, tylko dlatego, że ktoś nie może sobie ich wyobrazić". ${ }^{13}$ Jeśli ktoś akceptuje procesy darwinowskie, których nie tylko nie można zobaczyć, ale być może nigdy nie będziemy w stanie ich sobie wyobrazić, to jest niemożliwością zasugerowanie mu, że się myli.

Kenneth Miller przedstawił pomysł, jak można poznać, czy dobór naturalny jest w stanie utworzyć nieredukowalną złożoność. Uznał następnie, że test ten wypadł pomyślnie i zdecydowanie ogłosił, że hipoteza inteligentnego projektu została sfalsyfikowana („Behe się myli”). ${ }^{14}$ Lecz gdyby, czego jestem pewny, E. coli w rzeczywistości nie przeszła pomyślnie testu Millera na powstanie systemu laktozy, to czy Miller uważałby darwinizm za sfalsyfikowany? Prawie z pewno-

\footnotetext{
${ }^{13}$ Coyne, „God in the details...”.

${ }^{14}$ Miller, Finding Darwin's God..., s. 147.
} 
ścią - nie. Powiedziałby zapewne, że Barry Hall zaczął od niewłaściwego gatunku bakterii albo zastosował niewłaściwy nacisk selekcyjny, i tak dalej. A więc okazuje się, że jego test nie testował darwinizmu, a tylko ID. Takie samo jednokierunkowe testowanie zastosował Russell Doolittle. Wskazywał on na wyniki Buggego et al., aby argumentować przeciwko hipotezie ID. Lecz gdy wyniki te okazały się przeciwne temu, co pierwotnie sądził, nie odrzucił darwinizmu.

Wydaje się więc, choć być może jest to dla niektórych niezgodne z intuicją, że hipoteza ID jest podatna na falsyfikację - przynajmniej w dyskutowanych punktach. Darwinizm, z drugiej strony, wydaje się nieczuły na falsyfikację. Powód tego można zobaczyć, gdy sprawdzimy podstawowe twierdzenia tych dwóch teorii, mając na uwadze konkretny układ biochemiczny - taki jak, dajmy na to, wić bakteryjna. ID głosi, że „Żaden nieinteligentny proces nie mógł wytworzyć tego systemu”. Darwinizm zaś głosi, że „Pewien nieinteligentny proces (obejmujący dobór naturalny i przypadkową mutację) mógł wytworzyć ten system". Aby sfalsyfikować pierwsze twierdzenie, wystarczy pokazać, że co najmniej jeden nieinteligentny proces mógł wytworzyć ten układ. Aby sfalsyfikować drugie twierdzenie, trzeba by pokazać, że układ ten nie mógł się utworzyć przy pomocy żadnej, potencjalnie nieskończonej liczby możliwych nieinteligentnych procesów, a tego nie można efektywnie wykazać.

Uważam, że jest całkowicie przeciwnie niż sądzą profesor Coyne i National Academy of Sciences. Mocnym punktem hipotezy inteligentnego projektu jest jej wrażliwość na falsyfikację. (W rzeczywistości niektórzy moi religijni krytycy nie lubią teorii inteligentnego projektu właśnie dlatego, że boją się jej sfalsyfikowania i w związku z tym zadania przez naukę kolejnego ciosu również teologii). ${ }^{15}$ Słabym punktem darwinizmu jest jego oporność wobec falsyfikacji. Jakie świadectwo doświadczalne można znaleźć, aby sfalsyfikować pogląd, że zło-

\footnotetext{
${ }^{15}$ Zob. np. R.A. Flietstra, „A response to Michael Behe”, Books \& Culture, wrzesień/październik 1998, s. 37-38.
} 
żone mechanizmy molekularne wyewoluowały przy pomocy mechanizmów darwinowskich?

\section{Czym jest „nieredukowalna zlożoność” i co ona oznacza?}

Niektórzy recenzenci mojej książki skrytykowali koncepcję nieredukowalnej złożoności. W Boston Review biolog ewolucyjny $\mathrm{z}$ University of Rochester, H. Allen Orr, zgadza się, że wiele systemów biologicznych jest „nieredukowalnie złożonych”, lecz argumentuje, że ewolucjonizm darwinowski może, przynajmniej teoretycznie, bezpośrednio je wyjaśnić. Jednakże, jak pokażę, jego argument polega na zmianie definicji nieredukowalnej złożoności, co przysłania problem.

W swojej recenzji Orr wydaje się początkowo jasno rozumieć to, co ja nazywam „nieredukowalną złożonością”. O przykładzie, którego użyłem w Darwin's Black Box, pisze on: ,pułapka na myszy ma jasno określoną funkcję (zabicie myszy) i zrobiona jest z kilku części (podstawy, sprężyny, drążka, który zabija). Jeśli usunie się którąkolwiek z tych części, pułapka nie będzie działać. Dlatego jest nieredukowalnie złożona". ${ }^{16}$ Jak dotąd wszystko w porządku. Niemniej jednak, w późniejszym toku wywodów zdaje się on odchodzić od tego rozumienia:

System nieredukowalnie złożony można stopniowo zbudować dodając części, które - początkowo dając tylko przewagę - stają się istotne wskutek późniejszych zmian. Ta logika jest bardzo prosta. Pewna część (A) początkowo wykonuje jakąś pracę (i być może robi to niezbyt dobrze). Później zostaje dodana inna część (B), która ma być pomocna dla części (A). Ta nowa część nie jest istotna, stanowi tylko ulepszenie. Lecz jeszcze później część (A) (lub coś innego) może zmienić się w taki sposób, że część (B) stanie się teraz niezbędna. Proces ten trwa dalej wraz $\mathrm{z}$ dokładaniem kolejnych części do układu. W końcu

${ }^{16}$ H.A. ORR, „Darwin v. intelligent design (again)”, Boston Review, grudzień/styczeń 1996/1997, s. 28-31. 
wymaganych może być wiele części. ${ }^{17}$

Jak możemy teraz pogodzić powyższy paragraf z tym, w którym Orr początkowo przyznał, że jeśli usunąć którąkolwiek część pułapki na myszy, to przestanie ona działać? Zapytajmy na przykładzie owej pułapki, co mogłoby odpowiadać „,pewnej części (A)”, która ,początkowo wykonuje jakąś pracę"? W rzeczywistości celem tego przykładu było pokazanie, że nie istnieje żadna taka wykonująca jakąś pracę „część (A)”. Nie istnieje żadna „część (B)”, która ma być pomocna w stopniowym udoskonalaniu „części (A)”. Stopniowe dodawanie części jest niemożliwe w przypadku pułapki na myszy (lub przynajmniej możliwość taka jest bardzo daleka od oczywistości). Orr daje następnie biologiczny przykład tego, o czym myślał:

Przekształcenie pęcherzy powietrznych w płuca, które pozwoliły zwierzętom na oddychanie tlenem atmosferycznym, początkowo dawało im tylko przewagę: takie zwierzęta mogły penetrować teraz otwarte przestrzenie - jak suchy ląd które były wcześniej dla nich niedostępne z powodu braku płuc. Lecz w miarę jak ewolucja budowała tę adaptację (modyfikując na przykład kończyny do chodzenia), powstaliśmy my, istoty w pełni lądowe, a w konsekwencji tego płuca nie stanowią już luksusu - teraz są istotne. Sądzę, że puenta jest oczywista: mimo iż ten proces jest całkowicie darwinowski, otrzymaliśmy system nieredukowalnie złożony. ${ }^{18}$

Czym jest jednak układ nieredukowalnie złożony w przykładzie Orra? Pęcherzem pławnym? Płucem? Całym organizmem? Jaką ten system pełni funkcję? Czy jest to „pływanie”, „oddychanie”, „życie” czy coś zupełnie innego? Jeśli przyjmiemy, że mówiąc o układzie nieredukowalnie złożonym miał on na myśli, powiedzmy, płuco, to czy płuco można rozważać jako „pojedynczy układ”, jak tego wymaga

\footnotetext{
17 Tamże.

18 Tamże.
} 
moja definicja? ${ }^{19}$ Bez jakich części płuco przestanie funkcjonować, tak jak pułapka na myszy bez sprężyny? Czym jest „część (A)”, a czym „część (B)”? Jest to kompletnie niejasne - a z pewnością nie tak jasne, jak części i funkcja pułapki na myszy.

Zanim przedstawię moje pozostałe uwagi na ten temat, muszę przyznać, że ścisłe zdefiniowanie jakiegoś pojęcia stanowi nieustanną trudność, jak jest choćby w przypadku próby zdefiniowania „nauki”, „życia” czy „gatunku”. Co więcej, nie jestem filozofem; moim celem nie jest otrzymanie ciągu słów, które dadzą całkowitą definicję wyrażenia „nieredukowalna złożoność”. Chciałbym raczej zwrócić uwagę na pewną klasę systemów biochemicznych, które stanowią szczególne wyzwanie dla ewolucji darwinowskiej. Przykłady, które podałem w swojej książce - pułapka na myszy, rzęska, kaskada krzepnięcia i tak dalej - jasno pokazują potrzebę, aby niektóre układy miały wiele oddzielnych części, współpracujących ze sobą w pełnieniu pojedynczej funkcji. Uważam, że przykłady te lepiej ukazują pojęcie nieredukowalnej złożoności niż zaproponowana przeze mnie definicja, ${ }^{20}$ choć sądzę, że mimo to spełnia ona swoje zadanie.

Pamiętając o tym, zobaczymy, że Orr po prostu zamienił pojęcia w połowie swojej recenzji, co ujawniły jego sprzeczne uwagi zacytowane powyżej. Przeskoczył on od mojej idei nieredukowalnej złożoności do mglistego pojęcia, które można sparafrazować tak: ,jeśli usuniesz tę część, organizm w końcu umrze". Chętnie się zgodzę dla celów dyskusji, że istnieje pewna klasa zjawisk biologicznych potrzebnych do życia, które można stopniowo zmienić poprzez dobór naturalny; włączając nawet wspomniane przez Orra pęcherz pławny czy płuca (chociaż nie są to przykłady tak oczywiste, jak on sądzi). Problem jednak w tym, że nie są to systemy nieredukowalnie złożone ani nie usuwają one problemu układów nieredukowalnie złożonych, takich jak pułapki na myszy i rzęski. Gdyby systemy nieredukowalnie złożone

\footnotetext{
${ }^{19}$ BeHE, Darwin's Black Box..., s. 39.

${ }^{20}$ Tamże.
} 
były takie, jak je Orr opisał, to mógłby on je wyjaśnić z podobną łatwością, jak to zrobił z pęcherzem pławnym i płucami. (Ostatecznie, w skład tkanki płuc wchodzą przecież rzęski, a także wiele, wiele innych składników; dlatego właśnie Orr powinien łatwiej wyjaśnić same rzęski niż rzęski w połączeniu z pozostałymi składnikami). Dyskretnie zmieniona przez Orra definicja nieredukowalnej złożoności, nie mówi nam, jak mogła zostać wytworzona kaskada krzepnięcia krwi czy wić bakteryjna. Zamiast tego posunięcie owo odwraca naszą uwagę od tych cech systemów, które opierają się darwinowskim wyjaśnieniom.

Inni autorzy recenzji wysunęli argumenty podobne do argumentów Orra; zakładały one definicje nieredukowalnej złożoności inne od mojej. W Wall Street Journal Paul Gross układy biochemiczne porównuje do miast, do których cały czas można dodawać nowe elementy i zmieniać je. ${ }^{21}$ Ale analogia ta jest kiepsko dobrana, ponieważ żadne miasto nie przestaje kompletnie funkcjonować, gdy usunie się jakąś jego część, jak to zachodzi w przypadku pułapki na myszy czy rzęski. W Boston Review Douglas Futuyma pisze tak:

U ssaków następujące po sobie duplikacje genu beta dają początek łańcuchom gamma i epsilon, które charakteryzują hemoglobinę - odpowiednio - płodu i wczesnej postaci embrionu, a także uwydatniają pobieranie tlenu od matki. Skutki duplikacji genu, rozrzucone w czasie, doprowadziły więc do ,nieredukowalnie złożonego" systemu białek oddechowych u ssaków. ${ }^{22}$

Ale te kilka hemoglobin, które Futuyma nazywa „«nieredukowalnie złożonym» systemem białek oddechowych", w rzeczywistości nie stanowi układu nieredukowalnie złożonego w moim rozumieniu tego terminu. Nie oddziałują one ze sobą, jak to czynią części pułapki na myszy lub kaskady krzepnięcia. Funkcjonują one osobno i przez większą część procesu nie są nawet obecne w organizmie w tym samym

\footnotetext{
${ }^{21}$ P.R. Gross, „The disent of man”, Wall Street Journal, 30 lipca 1996, s. A12.

${ }^{22}$ D.J. Futuyma, „Miracles and molecules”, Boston Review, luty/marzec 1997, s. 29-30.
} 
czasie. Podobnie do Allena Orra, Futuyma milcząco zmienia znaczenie „nieredukowalnej złożoności”. Niestety, nie rozwiązuje to ukazanego przeze mnie problemu, ale go zaciemnia. (Na marginesie, trudno zrozumieć, jaki cel miał Futuyma opatrując cudzysłowem wyrażenie „nieredukowalna złożoność”. Nie mógł mnie cytować; nigdy nie używałem tego terminu w połączeniu $\mathrm{z}$ hemoglobiną - wręcz przeciwnie. Mógł go zamierzyć jako „cudzysłów ostrzegający”, aby uczulić czytelnika, by brał to wyrażenie z przymrużeniem oka. Ale skoro tylko on jeden zdecydował się na użycie owego terminu w połączeniu $\mathrm{z}$ hemoglobinami i następnie argumentował przeciw niemu, to efektem tego zabiegu jest dyskusja pozorna).

Inne pytanie o nieredukowalną złożoność zadał na swojej stronie internetowej David Ussery. Zauważył on, że podczas gdy wić bakteryjna u $E$. coli wymaga około 40 różnych białek, to u $H$. pylori już tylko 33. Skoro potrzeba mniej białek, to jak wić może być nieredukowalnie złożona? Można udzielić dwóch odpowiedzi na to pytanie. Po pierwsze, niektóre systemy mogą mieć części, które są konieczne do ich funkcjonowania, oraz inne części, które również się przydają, lecz nie są absolutnie wymagane. Chociaż można wyjąć radio $\mathrm{z}$ samochodu, nie powodując zaprzestania jego działania, to nie można pozbyć się akumulatora lub jakichś innych części i ciągle mieć działający samochód. Zdaje się, że sam Ussery uznaje to, pisząc: „mógłbym chętnie przyznać, że NADAL istnieje problem z ewolucją «najprostszej wici»", ${ }^{23}$ ale ma on nadzieję, że wyjaśni to duplikacja genu. Po drugie, trzeba uważać, by nie utożsamiać jednego białka $\mathrm{z}$ jedną „częścią” mechanizmu biochemicznego. Na przykład geny kodujące dwa białka w jednym organizmie mogą być połączone $\mathrm{w}$ pojedynczy gen $\mathrm{w}$ innym. Pojedyncze białko w jednym organizmie może pełnić funkcje kilku polipeptydów w drugim. Dwa białka mogą też łączyć się ze sobą, aby pełnić jedną funkcję (przykład stanowią

\footnotetext{
${ }^{23}$ David Ussery, „A biochemist's response to The Biochemical Challenge to Evolution”, Bios 1999, vol. 70, s. 40-45.
} 
podjednostki $\alpha$ i $\beta$ tubulin, tworzące razem mikrotubule, „część" rzęski eukariotycznej).

W swoim artykule Ussery mylnie przypisuje mi przekonanie, że wić bakteryjna wymaga 240 oddzielnych białek. Zamieszanie to powstało najwyraźniej z tego powodu, że na końcu rozdziału poświęconego rzęsce eukariotycznej i wici bakteryjnej stwierdziłem, iż typowa rzęska ma ponad dwieście różnych rodzajów białek. W następnym akapicie napisałem, że „wić bakteryjna, w dodatku do wcześniej omawianych białek, wymaga do funkcjonowania około czterdziestu innych białek". ${ }^{24}$ Mimo iż chodziło mi o białka wici, które omawiałem kilka stron wcześniej w tym rozdziale, Ussery zinterpretował to stwierdzenie, jakby dotyczyło ono również owych kilku setek białek rzęski. Powinienem pominąć taką pomyłkę, gdyż dla wykształconych czytelników jest raczej oczywiste, że nie traktuję jednakowo białek rzęsek i wici - są to przecież zupełnie odmienne struktury występujące $\mathrm{w}$ różnych typach organizmów. Jednakże w recenzji $\mathrm{w}$ Biology and Philosophy Bruce Weber pisze „Behe nie potrafi sobie wyobrazić, w jaki sposób coś, czemu brakuje wszystkich 240 składników wici, może napędzać bakterię. Lecz potrzeba tylko 33 białek, aby wytworzyć funkcjonalną wić u Helicobacter pylori". ${ }^{25}$ Weber podaje następnie stronę internetową Ussery'ego jako źródło, z którego skorzystał. Skoro błędne odczytanie mojej książki przez Ussery'ego wydaje się rozszerzać na innych i skoro naiwni czytelnicy mogą być pod większym wrażeniem spadku z 240 do 33 niż z 40 do 33 białek, muszę wyraźnie powiedzieć, że nie miałem na myśli tego, iż wić bakteryjna wymaga białek rzęski eukariotycznej!

Kilku recenzentów zakwestionowało twierdzenie, że nieredukowalna złożoność rzeczywiście oznacza inteligentny projekt. James Shapiro, pracujący nad mutacjami adaptatywnymi, w Boston

\footnotetext{
${ }^{24}$ Behe, Darwin's Black Box..., s. 72.

${ }^{25}$ Bruce Weber, „Irreducible complexity and the problem of biochemical emergence”, Biology \& Philosophy 1999, vol. 14, s. 593-605.
} 
Review ${ }^{26}$ pisze o ,pewnych postępach czynionych przez współczesne nauki o życiu, które ukazują mankamenty ortodoksyjnej teorii ewolucji”. Argumentuje on na rzecz „rosnącej zbieżności biologii i nauk informacyjnych, która daje możliwość naukowego dociekania możliwego inteligentnego działania komórek w czasie trwania ewolucji”. Wygląda na to, że Shapiro uważa, iż nieredukowalnie złożone struktury biochemiczne można wyjaśnić w niedarwinowski sposób bez doszukiwania się działania inteligencji poza obrębem komórek. W Biology and Philosophy Bruce Weber ${ }^{27}$ pisze, że praca Stuarta Kauffmana $\mathrm{i}$ inne na temat zjawiska samoorganizacji ,przerywają dychotomię, którą Behe ustanowił dla doboru i projektu". Shanks i Joplin jeszcze wyraźniej argumentowali w Philosophy of Science, że zjawiska samoorganizacji takie jak reakcja Biełousowa-Żabotyńskiego, pokazują, że nieredukowalna złożoność nie musi koniecznie wskazywać na inteligentny projekt. ${ }^{28}$ Odpowiedziałem na ich argument w osobnym artykule. ${ }^{29}$ Krótko mówiąc, złożoność jest cechą ilościową; systemy mogą być mniej lub bardziej złożone. Mimo iż wytwarza pewną złożoność, obserwowane w świecie fizycznym zjawisko samoorganizacji nie wytworzyło do tej pory złożonych i wyspecjalizowanych układów porównywalnych do nieredukowalnie złożonych systemów biochemicznych. Nie ma obecnie poważnych powodów, by sądzić, że zjawisko to może wyjaśnić układy biochemiczne takie jak wić bakteryjna czy kaskada krzepnięcia krwi.

Sądzę, że istotą tych wszystkich krytyk jest wskazanie na możliwość prowadzenia dalszych badań, które mogłyby pokazać, że nieredukowalną złożoność da się wyjaśnić za pomocą jakichś nieinteligentnych procesów (choć niekoniecznie darwinowskich). W tym punkcie

${ }^{26}$ J.A. SHAPIRo, „A third way”, Boston Review, luty/marzec 1997, s. 32-33.

${ }^{27}$ Bruce WEBER, „Irreducible complexity...”.

${ }^{28}$ Niall Shanks and Karl H. Joplin, „Redundant complexity: A critical analysis of intelligent design in biochemistry”, Philosophy of Science 1999, vol. 66, s. 268-282.

${ }^{29}$ M.J. Bene, ,Self-organization and irreducibly complex systems: A reply to Shanks and Joplin”, Philosophy of Science 2000, vol. 67, s. 155-162. 
zgadzam się z krytykami w zupełności. Przyznaję, że nie mogę odrzucić możliwości, iż dalsze badania wyjaśnią nieredukowalnie złożone systemy biochemiczne bez potrzeby odwoływania się do projektu. Stwierdziłem to zresztą w Darwin's Black Box. ${ }^{30}$ Zgadzam się, że nie mogę udowodnić, iż badania nad samoorganizacją nie doprowadzą $\mathrm{w}$ końcu do wyjaśnienia tych układów. Nie mogę też zdecydowanie powiedzieć, że idee profesora Shapiro o samoprojektujących się komórkach nie okażą się ostatecznie prawdziwe, albo że obecnie nieznane teorie wezmą górę. Ale niemożność zagwarantowania przyszłego biegu nauki jest wspólna każdemu, nie tylko tym, którzy popierają hipotezę inteligentnego projektu. Nikt nie może, na przykład, dać gwarancji, że dalsze badania nie ukażą więcej mankamentów teorii samoorganizacji, zamiast ich przezwyciężyć, albo że nawet nie uwidocznią więcej trudności związanych $\mathrm{z}$ doborem naturalnym.

Zgadzam się ze zdroworozsądkowym punktem widzenia, że nikt nie może przewidzieć przyszłości nauki. Zdecydowanie nie podzielam poglądu, iż z powodu niemożliwości zagwarantowania sukcesu teorii inteligentnego projektu można ją odrzucić lub w ogóle się nią nie zajmować. Gdyby nauka działała w taki sposób, nigdy nie dociekanoby żadnej teorii, ponieważ żadna nie gwarantuje wiecznego sukcesu. Jeśli ignoruje się jakąś hipotezę $\mathrm{z}$ tego powodu, że być może kiedyś okaże się ona błędna, to paradoksalnie bierze się niefalsyfikowalność za konieczną cechę teorii naukowej. Chociaż filozofowie nauki dyskutowali nad tym, czy od teorii naukowej wymaga się falsyfikowalności, to - o ile wiem - nikt nie uważał, że jej cechą konieczną jest niefalsyfikowalność.

Nauka musi kierować się aktualnie posiadanymi danymi, ponieważ nikt nie jest w stanie przewidzieć przyszłości. Istnieje obecnie tylko jedno zjawisko, które ukazuje zdolność do tworzenia nieredukowalnej złożoności - jest to działanie inteligentnego czynnika. Wydaje mi się, że sama ta sytuacja uzasadnia zajmowanie się w biochemii hipotezą inteligentnego projektu. W swojej ostatniej książce Tower of Babel:

\footnotetext{
${ }^{30}$ BEHE, Darwin's Black Box..., s. 203-204.
} 
The Evidence Against the New Creationism filozof nauki, Robert Pennock, dowodzi, że nauka powinna unikać teorii inteligentnego projektu, ponieważ koniecznie musi ona kierować się „naturalizmem metodologicznym". ${ }^{31}$ Odpowiedziałem Pennockowi gdzie indziej. ${ }^{32}$ Krótko mówiąc, nauka powinna śledzić dane bez względu na to, gdzie one prowadzą, nie ustalając warunków wstępnych. Więcej, kwestia tożsamości projektanta pozostaje otwarta (zobacz poniżej) - tak jak przyczyna Wielkiego Wybuchu jest otwarta od dziesiątek lat. Dlatego nauka - przy użyciu sobie właściwych metod - może zajmować się, tak dalece, jak to tylko możliwe, teoriami, które niosą pozanaukowe skojarzenia (takimi jak teoria Wielkiego Wybuchu ${ }^{33}$ czy inteligentnego projektu).

\section{Czy możemy - czy to w ogóle możliwe - wykrywać projekt w komórce?}

Niektórzy recenzenci argumentowali przeciwko słuszności wnioskowania o inteligentnym projekcie na podstawie świadectwa biochemicznego. W wyżej omawianej recenzji Allen Orr podnosi intrygującą kwestię pojmowania projektu. Pisze on tak:

${ }^{31}$ R. Pennock, Tower of Babel: The Evidence Against the New Creationism, MIT Press, Cambridge, Massachusetts 1999.

${ }^{32}$ M.J. Bene, „The God of Science: The case for intelligent design”, The Weekly Standard, 7 czerwca 1999, s. 35-37.

${ }^{33}$ To, że teoria Wielkiego Wybuchu niesie pozanaukowe skojarzenia, można poznać po reakcji tych, którzy nie widzą mile tych skojarzeń. Na przykład w artykule wstępnym w 1989 roku w Nature, o intrygującym tytule „Down with the Big Bang” [Precz z Wielkim Wybuchem], John Maddox napisał, że „Kreacjoniści i ludzie o podobnych przekonaniach poszukując poparcia dla swoich teorii znajdują dostateczne uzasadnienie w doktrynie Wielkiego Wybuchu. Mogą oni powiedzieć, że doktryna ta dotyczy tego, kiedy (i jak) Wszechświat został stworzony” (John MAdDox, „Down with the Big Bang”, Nature 1989, vol. 340, s. 425). 
Wiemy, że są ludzie robiący takie rzeczy jak pułapki na myszy. (Nie naigrawam się w tej chwili - jestem całkowicie poważny). Dokonując wyboru między hipotezą projektu a hipotezą darwinizmu, uważamy projekt za przekonujące wyjaśnienie pochodzenia pułapek na myszy tylko dlatego, że posiadamy niezależną wiedzę, że istnieją stworzenia zwane ludźmi, które skonstruowały całą różnorodność urządzeń mechanicznych; gdybyśmy tego nie wiedzieli, to istnienie pułapek na myszy stanowiłoby uzasadniony problem naukowy. ${ }^{34}$

Orr mówi więc, że wiemy, iż pułapki na myszy zostały zaprojektowane przez ludzi, ale nie widzieliśmy, czy nieredukowalnie złożone systemy biochemiczne zostały zaprojektowane, nie możemy zatem wnioskować, że tak rzeczywiście było.

Chociaż jest to ciekawa uwaga, sądzę, że jego rozumowanie jest niepoprawne. Rozważmy projekt SETI (Search for Extraterrestial Inteligence) [poszukiwanie inteligencji pozaziemskiej], w którym naukowcy przeszukują przestrzeń kosmiczną w celu wykrycia fal radiowych, które mogły zostać wysłane przez kosmitów. Uczeni ci uważają, że mogą odróżnić zaprojektowana falę radiową (niosącą jakąś wiadomość) od radiowego szumu tła kosmicznego. Nie widzieliśmy jednak nigdy kosmitów wysyłających wiadomości za pomocą radia; w ogóle nigdy ich nie spotkaliśmy. Niemniej jednak pracownicy SETI, przez lata finansowo wspierani przez rząd, są pewni, że potrafią wykrywać inteligentnie zaprojektowane zjawiska, nawet jeśli nie wiedzą, kto je wytworzył.

Znaczenie hipotezy inteligentnego projektu $\mathrm{w}$ biochemii jest zrozumiałe. Projekt to oczywisty wniosek, wysunięty raczej na podstawie samego zaprojektowanego układu niż na podstawie wcześniejszej wiedzy, kim jest projektant. Nawet jeśli projektant jest bytem całkowicie odmiennym od nas, nadal możemy wnioskować o projekcie, jeśli zaprojektowany system ma szczególne cechy (takie jak nieredukowalna złożoność) wymagające inteligentnego przygotowania. (Jedną z formalnych analiz tego, jak dochodzimy do wniosku o projekcie,

\footnotetext{
${ }^{34}$ H.A. OrR, „H. Allen Orr responds”, Boston Review, luty/marzec 1997, s. 35-36.
} 
przedstawił w swojej ostatniej monografii - The Design Inference William Dembski). ${ }^{35}$

Możemy dalej badać rozumowanie Orra, pytając, skąd wiemy, że coś zostało inteligentnie zaprojektowane, nawet jeśli jest to faktycznie wynikiem ludzkiej działalności. Ludzie są przecież zaangażowani w rozmaite rodzaje aktywności, którym nie przypisalibyśmy inteligencji. Spacerując - na przykład - w lesie, ktoś może deptać stopami rośliny, przypadkowo łamać gałęzie drzew, i tak dalej. Dlaczego nie przypisujemy tego aktywności celowej? $Z$ drugiej strony, dlaczego pewnie wnioskujemy, widząc małe sidła (zrobione z kijków i sznura) w lesie, zaprojektowane najwyraźniej w celu złapania królika, że części tych sideł zostały celowo ułożone przez inteligentny czynnik? Dlaczego rozpoznajemy celowość w sidłach, ale nie w śladach? Thomas Reid argumentował w odpowiedzi na sceptycyzm Hume'a, że inteligencję rozpoznajemy tylko na podstawie jej skutków; nie możemy bezpośrednio obserwować inteligencji. ${ }^{36}$ Wiemy o inteligencji ludzkiej na podstawie jej zewnętrznych działań. Oddzielamy inteligentne ludzkie działania od nieinteligentnych za pomocą zewnętrznego świadectwa. Inteligencja, ludzka bądź nie, jest widoczna tylko w swoich skutkach.

Michael Ruse w Boston Review stawia inny zarzut, mówiąc, że naukowcy jako naukowcy po prostu nie mogą odwoływać się do projektu.

Projekt nie jest czymś, co można dodać do nauki na równych prawach - cuda czy molekuły, wybieraj. Hipoteza projektu to interpretacja nadająca doświadczeniu ogólny metafizyczny lub teologiczny sens. ${ }^{37}$

\footnotetext{
${ }^{35}$ W.A. Dembski, The Design Inference: Eliminating Chance Through Small Probabilities, Cambridge University Press, Cambridge 1998.

${ }^{36}$ W.A. Dembsкi, Intelligent Design: The Bridge Between Science and Theology, InterVarsity Press, Downers Grove, Illinois 1999.

${ }^{37}$ M. Ruse, „Enough speculation”, Boston Review, luty/marzec 1997, s. 32-33.
} 
Jednakże w przeciwieństwie do twierdzenia Ruse'a, wielu naukowców odwoływało się już do projektu. Wspomniałem wyżej o programie SETI; jest jasne, że ci naukowcy uważają, iż potrafią wykrywać projekt (i to projekt nie będący dziełem człowieka). Uczeni pracujący dla potrzeb sądów rutynowo podejmują decyzje, czy czyjaś śmierć została zaplanowana (morderstwo), czy też była dziełem przypadku. Archeolodzy rozstrzygają, czy jakiś kamień jest zaprojektowanym artefaktem, czy też jego ukształtowanie było przypadkowe. Kryptolodzy starają się odróżnić zakodowaną wiadomość od przypadkowego szumu. Wydaje się niedorzeczne, żeby którykolwiek z tych naukowców postrzegał swoją pracę jako próbę nadania „doświadczeniu metafizycznego lub teologicznego sensu". Oni po prostu wykonują swoją pracę.

Ruse myślał być może o tym, że uczeni nie mogą specjalnie odwoływać się do Boga czy do czegoś nadnaturalnego. Biolog ewolucyjny, Douglas Futuyma, powtarza opinię Ruse'a, używając porywającej retoryki:

Gdy naukowcy odwołują się do cudów, przestają uprawiać naukę [...]. Behe, widząc cud w każdej molekule, chciałby doprowadzić nas do uznania porażki rozumu, do stracenia nadziei na zrozumienie, do zadowolenia się niewiedzą. Nawet gdyby biolodzy z dnia na dzień uzyskiwali coraz większą wiedzę i wgląd w procesy życiowe, Behe radziłby nam, abyśmy się poddali. ${ }^{38}$

Mówiąc o „cudach” - polegając na retorycznym efekcie, uzyskanym dzięki pejoratywnym konotacjom tego słowa, gdy używa się go w kontekście naukowym - Ruse i Futuyma przypisują mi stanowisko, którego starannie próbowałem uniknąć w mojej książce. Przyznaję, że większość ludzi (łącznie ze mną) przypisuje projekt Bogu częściowo opierając się na innych, nienaukowych osądach - nie twierdzę jednak, że świadectwo biochemiczne nieuchronnie prowadzi do

\footnotetext{
${ }^{38}$ FutUYMa, ,Miracles and molecules...”.
} 
wniosku o tym, kto jest projektantem. W rzeczywistości wyraźnie powiedziałem, że z naukowego punktu widzenia ta kwestia pozostaje otwarta. ${ }^{39}$ Nie zrobiłem tego z nieśmiałości, lecz po prostu dlatego, że ograniczam się wyłącznie do stwierdzenia, jaką hipotezę - moim zdaniem - świadectwo to popiera. Podam przykład dla zilustrowania tego, co mam na myśli. Francis Crick wysunął słynne przypuszczenie, że to kosmici mogli rozmyślnie rozsiać życie na Ziemi. ${ }^{40}$ Gdyby Crick powiedział, iż uważa, że kaskada krzepnięcia została zaprojektowana przez kosmitów, nie mógłbym wskazać na biochemiczne cechy tego systemu, aby udowodnić, że jest on w błędzie. Świadectwo biochemiczne silnie wskazuje na projekt, ale nie daje wiedzy, kto był projektantem.

Powinienem dodać, że nawet jeśli ktoś za projektanta uważa Boga, zgoda na teorię inteligentnego projektu nie musi za sobą pociągać zgody na „cuda”. Przynajmniej nie bardziej niż myślenie, że prawa przyrody zostały zaprojektowane przez Boga - jak widzieliśmy, jest to pogląd utrzymywany przez National Academy of Sciences. ${ }^{41} \mathrm{~W}$ obu przypadkach można utrzymywać, że informacja konieczna dla dalszego rozwoju życia istniała na samym początku Wszechświata i nie wymagała dalszej ,interwencji” płynącej spoza przyrody. W pierwszym przypadku informacja jest zawarta tylko w ogólnych prawach. W drugim przypadku - tkwi ona także w innych czynnikach. Różnice między tymi przypadkami łatwo można sprowadzić do kwestii, czy bardziej lub mniej wyraźna zaprojektowana informacja istniała na początku - co trudno uznać za kwestię zasady.

Skoro jesteśmy przy temacie Boga, należy uczynić jeszcze jedną uwagę: wielu wybitnych naukowców, spośród których pewni winią mnie za sugerowanie hipotezy projektu, samemu argumentuje na rzecz wyciągania ateistycznych wniosków z danych biologicznych. Profesor

\footnotetext{
${ }^{39}$ BeHE, Darwin's Black Box..., s. 245-250.

${ }^{40}$ Francis Crick and L.E. Orgel, „Directed panspermia”, Icarus 1973, vol. 19, s. 341346.

${ }^{41}$ National Academy of Sciences, Science and creationism....
} 
Futuyma napisał na przykład: „są tacy, którzy wzdragają się przed wnioskiem, że gatunek ludzki nie został zaprojektowany, nie ma celu i jest wytworem wyłącznie procesów mechanicznych - ale właśnie to zdaje się głosić ewolucjonizm". ${ }^{42}$ Russell Doolittle natomiast odnośnie kaskady krzepnięcia krwi zauważa: „...żaden Stwórca nie zaprojektowałby tak pokrętnego i przekombinowanego systemu". ${ }^{43}$ Jednakże tym, którzy używają danych biologicznych, by argumentować, że życie nie ukazuje świadectwa empirycznego na rzecz projektu, nie wypada narzekać, gdy inni używają świadectwa biologicznego, aby opowiadać się za poglądem przeciwnym.

\section{IV. „Kapitulacja” w obliczu ,ignorancji”}

Niektórzy recenzenci odrzucili wniosek o projekcie jako „argument z ignorancji” lub argument z „Boga luk”. Odrzucenie owo może przybierać kilka postaci. Jedną z nich przedstawia biolog ewolucyjny, Andrew Pomiankowski z University of London, który pisze tak:

Wielu biochemików ma tylko niewielkie pojęcie o ewolucji, czy też nie bardzo się nią interesuje. Jak wykazał Behe, na ponad tysiąc naukowych artykułów o biochemii rzęsek zdołał znaleźć tylko garstkę, które naprawdę odnosiły się do ewolucji. Ta obojętność jest powszechna. ${ }^{44}$

Pomiankowski argumentuje więc, że nie znamy odpowiedzi, ponieważ nikt ich nie szukał, a biochemicy nie robili tego, bo mało interesują się tym tematem.

\footnotetext{
${ }^{42}$ D.J. FutuYma, Science on Trial, Pantheon Books, New York 1982.

${ }^{43}$ Doolitle, „A delicate balance...”.

${ }^{44}$ A. Pomiankowski, „The God of the tiny gaps”, New Scientist, 14 września 1996.
} 
Choć na pierwszy rzut oka przekonująca, interpretacja ta jest niedobra, gdyż można wykazać, że biologowie molekularni interesują się ewolucją. (Nie trzeba oficjalnie nazywać się „biochemikiem”, aby zajmować się takimi problemami. Zajmują się nimi biolodzy molekularni, genetycy, immunolodzy, embriologowie). Autorzy dużej ilości książek i artykułów, wymienieni na stronach internetowych Johna Catalano i Davida Ussery'ego, w sposób wyraźny interesują się ewolucją (zobacz moją dyskusję na temat literatury ewolucjonistycznej na stronie internetowej www.discovery.org), tak jak i autorzy mnóstwa innych badań, które dotyczą porównywania sekwencji. Skoro opublikowano wiele artykułów z szeroko rozumianej dziedziny ewolucji molekularnej, to należy zapytać, dlaczego jest tak mało publikacji na konkretny temat darwinowskiej ewolucji systemów nieredukowalnie złożonych? Pomiankowski wysuwa wniosek, że dzieje się tak, gdyż jest to bardzo trudny problem; ${ }^{45}$ ja sugeruję, że jest on trudny, ponieważ systemy nieredukowalnie złożone słabo pasują do ram gradualistycznej teorii, takiej jak darwinizm.

Mniej rozsądną, moim zdaniem, postać oskarżenia o „ignorancję” przedstawił Neil Blackstone. Blackstone, biolog ewolucyjny z Northern Illinois University, wysuwa względem mnie formalne oskarżenie o popełnienie błędu logicznego - ,argumentum ad ignorantiam” - tak samo zatytułowana jest jego recenzja. ${ }^{46}$ Aby nadać swemu oskarżeniu wagę, cytuje on nawet podręcznik do filozofii napisany przez Irvinga Copiego. Jednakże ci, którzy do odrzucenia pewnej hipotezy stosują logikę, powinni się upewnić, że stoją na bardzo twardym logicznym gruncie. Blackstone nie stoi.

Copi definiuje ów błąd logiczny następująco: „argumentum ad ignorantiam jest popełniany, gdy dowodzi się prawdziwości zdania na samej podstawie tego, że nie udowodniono jego fałszywości, albo gdy dowodzi się, że jest ono fałszywe, gdyż nie udowodniono jego praw-

\footnotetext{
${ }^{45}$ Tamże.

${ }^{46}$ N.W. Blackstone, „Argumentum ad ignorantiam”, Quarterly Review of Biology 1997, vol. 72 , s. $445-447$.
} 
dziwości”. ${ }^{47} \mathrm{Z}$ pewnością nie dowodziłem jednak, że hipoteza darwinowskiej ewolucji biochemicznej złożoności jest fałszywa „na samej podstawie tego", że nie udowodniono jej prawdziwości. Nie powiedziałem też, że hipoteza inteligentnego projektu jest prawdziwa „na samej podstawie tego", że nie udowodniono jej fałszywości. Aby położyć podwaliny pod propozycję inteligentnego projektu, szeroko dowodziłem, że kaskada krzepnięcia krwi i inne systemy nie zostały wyjaśnione przez darwinizm. Było to konieczne, ponieważ wielu ludzi odnosi wrażenie, że teoria darwinowska dała już zadowalające wyjaśnienie właściwie wszystkich aspektów życia. Moim pierwszym zadaniem było pokazanie czytelnikom, że to wrażenie jest mylne.

Mój argument nie zatrzymuje się jednak w tym miejscu. Poświęciłem wiele stron swojej książki pokazując, że istnieje strukturalny powód - nieredukowalna złożoność - by sądzić, że sukces wyjaśnień darwinowskich jest nieprawdopodobny. Co więcej, dowodziłem, iż nieredukowalna złożoność oznacza inteligentny projekt. Poświęciłem kilka rozdziałów na wyjaśnienie, w jaki sposób pojmujemy projekt, dlaczego systemy biochemiczne spełniają jego kryteria, a także wysuwałem zarzuty względem hipotezy inteligentnego projektu. Okrojenie mojej koncepcji i mówienie, że popełniłem błąd logiczny argumentum ad ignorantiam jest, moim zdaniem, postępowaniem nieuczciwym.

Zbadajmy zawiłości logiki formalnej trochę głębiej. Choć Blackstone o tym nie wspomniał, Copi ma więcej do powiedzenia o argumencie $\mathrm{z}$ ignorancji:

W tym miejscu powinniśmy wysunąć pewne zastrzeżenie. Czasami można bezpiecznie zakładać, że jeśli nastąpiło pewne zdarzenie, to wykwalifikowani badacze mogą odkryć świadectwo za nim przemawiające. W takich okolicznościach jest zupełnie rozsądne traktowanie braku dowodu jego wystąpienia jako pozytywnego dowodu świadczącego o tym, że zdarzenie to nie nastąpiło. ${ }^{48}$

\footnotetext{
${ }^{47}$ I.M. CopI, Introduction to Logic, Macmillan, New York 1953.

${ }^{48}$ Tamże.
} 
Chociaż nie ograniczam swojego argumentu do braku świadectwa empirycznego na rzecz darwinowskiej ewolucji nieredukowalnie złożonych systemów biochemicznych, to w momencie, gdy wykwalifikowani badacze (tacy jak, powiedzmy, badacze krzepnięcia krwi) przychodzą z pustymi rękami, jest „zupełnie rozsądne” uważać to za argument przeciw darwinizmowi. (Sam ten fakt nie jest, oczywiście, pozytywnym świadectwem na rzecz projektu). Mimo iż brak postępu nie jest „dowodem” błędności darwinizmu, jest to $\mathrm{z}$ pewnością znaczący argument do rozważenia.

W łagodniejszej wersji ,argumentu z ignorancji” inni naukowcy stawiali zarzut, że odwoływanie się do hipotezy inteligentnego projektu jest równoznaczne z ,kapitulacją”. Na przykład w Forward Marc Lipsitch, biolog ewolucyjny z Emory University, zauważa:

[Behe] poprawnie sugeruje, że kompletna teoria ewolucji powinna obejmować wyjaśnienie tego, jak skomplikowane systemy chemiczne w naszych organizmach powstały (lub mogą powstać) z molekuł nieożywionych, po jednym kroku naraz. Pytanie pana Behe'ego jest postawione uczciwie, ale zamiast zaproponowania serii eksperymentów, które mogłyby dać odpowiedź na to pytanie, po prostu załamuje on ręce. ${ }^{49}$

Niestety, mamy do czynienia z błędnym kołem w rozumowaniu: argument ten zakłada, że życie nie zostało zaprojektowane, a to jest zagadnienie tutaj dyskutowane. Jeśli życie nie zostało zaprojektowane, to teoria inteligentnego projektu rzeczywiście prowadzi ostatecznie $\mathrm{w}$ ślepą uliczkę (jeśli nie do całkowitej „kapitulacji”). Jednakże jeżeli aspekty życia faktycznie zostały zaprojektowane, to w ślepą uliczkę prowadzi poszukiwanie rzekomo tworzących je nieinteligentnych mechanizmów. Jak jednak rozstrzygniemy w przyszłości, która z tych możliwości jest prawidłowa?

\footnotetext{
${ }^{49}$ M. Lipsitch, „Fighting an evolutionary war”, Forward, 25 października 1996, vol. 9.
} 
Rozstrzygnięcie tej kwestii z góry jest niemożliwe. Nauki przyrodnicze mogą tylko iść śladem danych, gdy te stają się dostępne.

Michael J. Behe 